\title{
Modern problems in marine biodiversity records - illustrated by the case of the Caribbean Pelia mutica (Gibbes, 1850) confirmed in Brazil
}

\author{
Bruno Welter Giraldes ${ }^{1,2^{*}}$, David Smyth ${ }^{1}$ and Mark Chatting ${ }^{1}$
}

\begin{abstract}
This report confirms the presence of Pelia mutica in Brazil, extending its range by approximately $4000 \mathrm{~km}$ south to the southwestern Atlantic Ocean from its most southerly recorded distribution. The presence of this small ornamental marine crab with cryptic habits and native to Caribbean waters raises some challenging questions about modern problems in marine biodiversity records. This case is an excellent example in relation to the importance of diligent biodiversity monitoring. It highlights why the skills of taxonomists are paramount when identifying silent biological invasion of supposedly irrelevant alien species in a modern Anthropocene epoch within an alarming scenario of defaunation and mass extinction.
\end{abstract}

Keywords: Teardrop crab, Coastal reefs, Ornamental decapod, Silent bioinvasion, Scuba diving, Nocturnal survey, Majoidea: Pisinae

\section{Introduction}

According with $\mathrm{Ng}$ et al. (2008) there are six known species representing the genus Pelia Bell, 1836. Among them, four species were described in the Western Atlantic Ocean Pelia deflecta Boone, 1927, Pelia mutica (Gibbes 1850), Pelia pacifica A. Milne-Edwards, 1875 and Pelia rotunda A. Milne-Edwards, 1875 (Milne-Edwards, 1875; Rathbun, 1925; Boone, 1927; Williams, 1984; Melo, 1996). $P$. deflecta was only reported by Boone (1927) and the last report for P. pacifica was in (Rathbun, 1925). Since then, there have only been two confirmed species in the Western Atlantic Ocean, Pelia rotunda in South America (Melo, 1996) and Pelia mutica in Central and North America (Williams, 1984). These two species were theoretically isolated in different eco-regions separated by the biogeographic barrier of Amazon-Orinoco plume (Spalding et al., 2007).

Pelia mutica is a known ornamental species traded in the aquarium industry as a decorator teardrop crab

\footnotetext{
* Correspondence: brunoweltergiraldes@gmail.com

${ }^{1}$ Qatar University, Environmental Studies Center, P.O. Box: 2713, Doha, Qatar

${ }^{2}$ Universidade Federal de Pernambuco, Laboratório de Carcinologia do Museu Oceanográfico, Recife, PE, Brazil
}

(Calado et al., 2003). It was previously reported in Brazilian waters by Gouvêa \& Leite (1980) and Gouvêa (1986), however due to an absence of deposited material, morphological description or figures and a sequence of incorrect identifications within their studies this crab's presence was considered doubtful (Almeida \& Coelho, 2008; Coelho et al., 2008). This is compounded by a current lack of new research focusing on ecology, phylogeny and descriptive investigations into the morphological characteristics of these species. The absence of recent scientific material on the species becomes evident when we consider that the most significant references comparing the Pelia species are from key identifications in the late $19^{\text {th }}$ and early $20^{\text {th }}$ centuries (Milne-Edwards, 1875; Rathbun, 1925).

This report confirms the presence of Pelia mutica in Brazil, extending its range to the southwestern Atlantic Ocean. Its presence focuses the importance of diligent biodiversity monitoring and how the skills of taxonomists are paramount when identifying biological invasion of alien species in a modern Anthropocene epoch within a scenario of defaunation and mass extinction. 


\section{Material and Methods}

The biological material was collected during nocturnal SCUBA dives in the reefs of Porto de Galinhas $\left(8^{\circ} 30^{\prime} \mathrm{S} /\right.$ $35^{\circ} 00^{\prime} \mathrm{W}$ ) in 2005 (Pernambuco state - Brazil). Specimens were observed and collected during nocturnal underwater visual census analysis; they were identified and deposited in the Oceanographic museum Dr. Petrônio Alves Coelho at Federal University of Pernambuco (MOUFPE) and previously used in a $\mathrm{PhD}$ thesis (Giraldes, 2012) and in a scientific article (Giraldes et al., 2012). It was erroneously identified in those first reports as Pelia rotunda.

Reviewing taxonomic references about decapod species (Milne-Edwards, 1875; Rathbun, 1925; Williams, 1984; Melo, 1996) noted some morphological features and habitat preferences which drew attention to the deposited species which were re-analysed and re-identified as Pelia mutica.
In an attempt to assist in the collation of information for this species some morphological differences among the existing species of genus Pelia in the West Atlantic Ocean are presented.

\section{Results}

Infraorder Brachyura Linnaeus 1758

Superfamily Majoidea Samouelle 1819

Family Epialtidae Macleay 1838

Pelia mutica (Gibbes 1850)

Figure 1

\section{References}

Milne-Edwards, 1875:73; Rathbun, 1925:278; Lemaitre, 1981:246; Williams, 1984:321; Abele \& Kim, 1986:553; Hernández-Ávila et al., 2007:39.
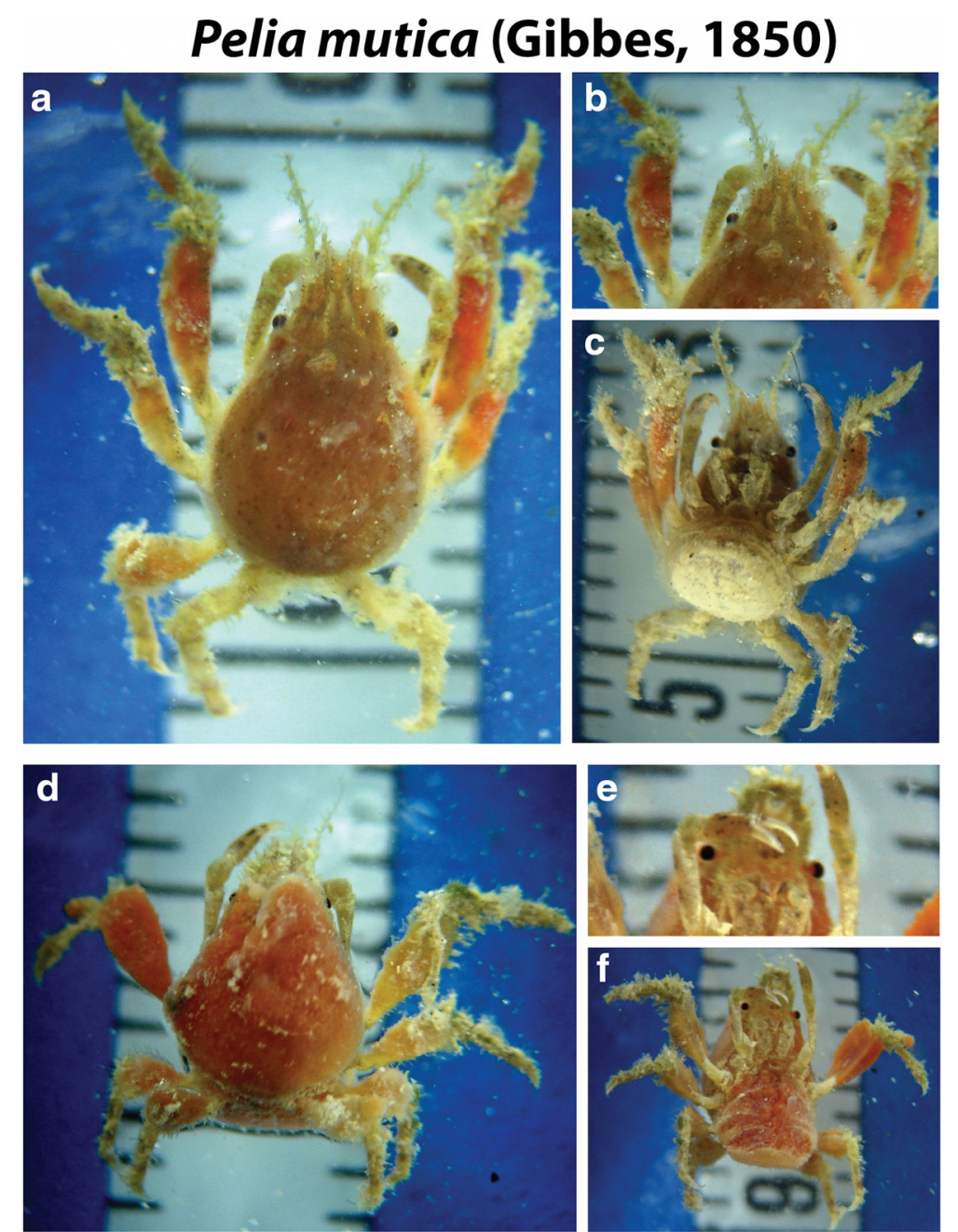

Fig. 1 Pelia mutica (Gibbes 1850) collected in this study. Specimen 1 with the sponge removed [A-C], being: a emphasizing the body shape, b rostrum and frontal portion, $\mathbf{c}$ ventral portion with the large abdomen without eggs. Specimen 2: female with eggs still with the sponge before the identification, being: $\mathbf{d}$ the body with sponge hiding the elongated body, e detail of cheliped with dark spots, $\mathbf{f}$ inferior part of body with the red eggs 


\section{Material examined}

1 Female with eggs, (Carapace Length: $6.3 \mathrm{~mm} /$ Carapace width: $3.8 \mathrm{~mm}$ ) and 1 Female (Carapace Length: $7 \mathrm{~mm} /$ Carapace width: $4.8 \mathrm{~mm}$ ) shallow reef Station of Porto de Galinhas beach $\left(8^{\circ} 30^{\prime} \mathrm{S} / 35^{\circ} 00^{\prime} \mathrm{W}\right) 1 \mathrm{~m}$ deep, collected 23.April.2005 (MOUFPE - 15.030 as Pelia rotunda).

\section{Material observed}

Two specimens on the reef edge at $1 \mathrm{~m}$ deep on encrusted orange sponge covered by the same sponge 23.April.2005 (the specimens captured for identification in laboratory); 1 specimen on an encrusted orange sponge (covered by the same sponge) on one an outcrop of reef at $3 \mathrm{~m}$ deep 24.April.2005; 1 specimen on the reef edge at $0.5 \mathrm{~m}$ deep on the hydrocoral Millepora alcicornis Linnaeus, 1758 covered by orange sponge, 25.April.2005; 1 specimen on encrusted black sponge on the reef edge at $1.5 \mathrm{~m}$ deep 26.April.2005. All specimens were observed during night dives on the reefs of Porto de Galinhas beach $\left(8^{\circ} 30^{\prime} \mathrm{S} / 35^{\circ} 00^{\prime} \mathrm{W}\right)$.

\section{Distribution}

Western Atlantic Ocean: from North America and Central America to the north coast of South America. More specifically from Buzzards Bay and Vineyard Sound in Massachusetts (northern record), including Port Mansfield, Willacy in Texas, Cuba, Puerto Rico and St. Thomas in the US Virgin Islands to the coast of Cartagena in Colombia and Cubagua Island in Venezuela (southern record).

\section{Comparison of species within genus Pelia in Brazil}

The main morphological characteristics in the key identification, which differentiate between $P$. rotunda and $P$. mutica were reported in Milne-Edwards (1875:73) and Rathbun (1925:278). Those distinctive characteristics are the length and convexity of carapace, larger and more convex in $P$. rotunda (almost as long as large); carapace surface is more flat in $P$. mutica and outstanding in gastric and cardiac areas in $P$. rotunda; with the rostrum shape smaller and more deflexed directed downward in $P$. rotunda (Fig. 2). Another morphological difference not included in the key identification is the proportion

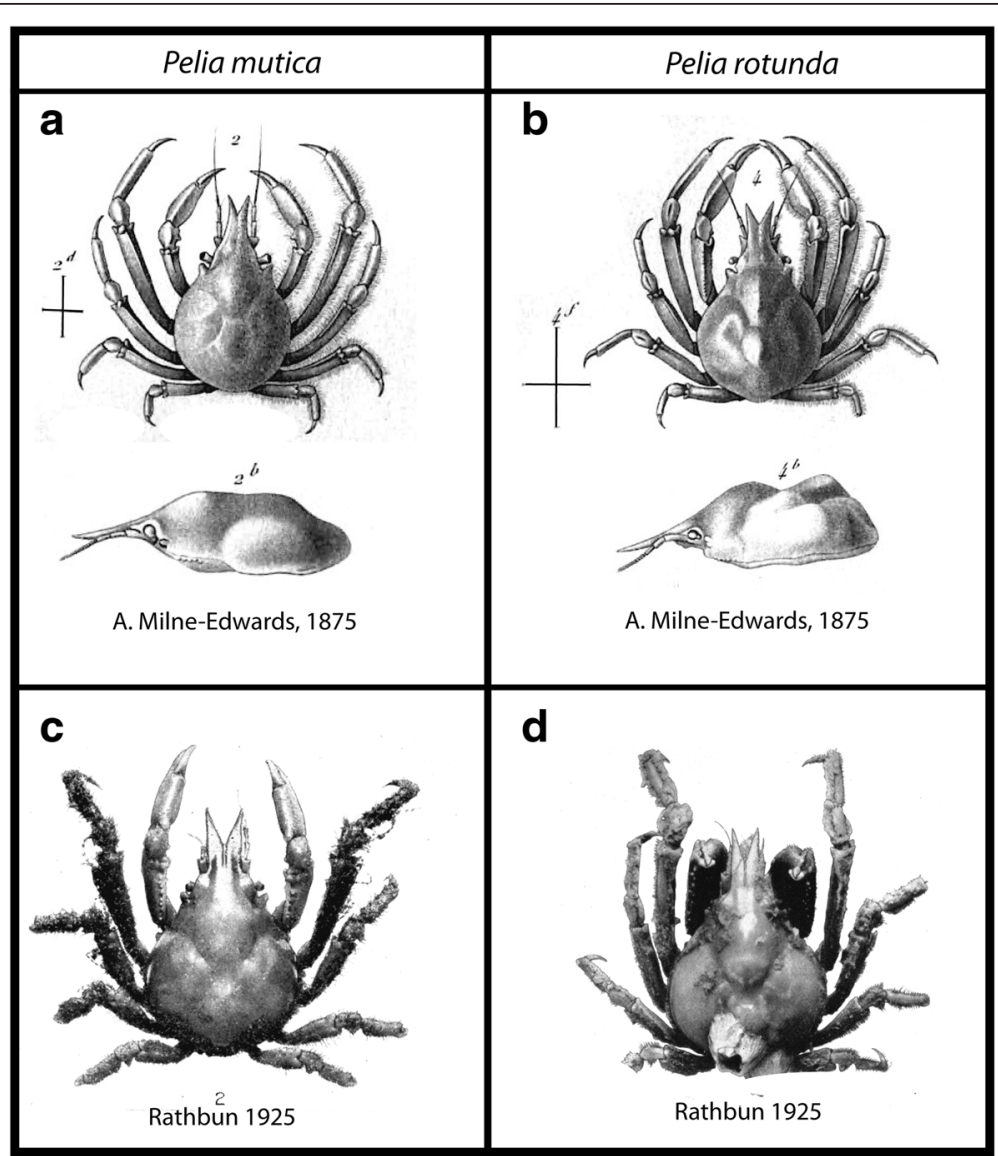

Fig. 2 Comparative table with (a, c) Pelia mutica (Gibbes, 1850) and (b, d) Pelia rotunda A. Milne-Edwards, 1875 with the images reported by Milne-Edwards (1875) in plate 16 and in Rathbun (1925) plate 98 and plate 100 respectively 
of the pereiopods where the $2^{\circ}$ and $3^{\circ}$ are much longer than $4^{\circ}$ and $5^{\circ}$ in $P$. mutica (see description and picture in Williams, 1984:321 and Fig. 1 here) while in P. rotunda the pereiopods slowly decrease in length (see Melo, 1996:265 and Braga et al., 2005:14). Pelia mutica sampled here like the descriptions reported by Williams 1984 presents dark spots in the propod of chelipeds (Fig. 1) even when conserved in alcohol; however this characteristic is not reported for P. rotunda (Melo 1996) and is absent in the figure in Braga et al. (2005:14 fig. $20)$. This therefore can be considered as one of the characteristics for visual differentiation. There are also some important differences in habitat preference, as $P$. rotunda has been reported in soft substrates in the southwestern Atlantic (Fransozo et al., 1992; Melo, 1996; Bertini et al., 2004; Braga et al., 2005) and P. mutica has been reported as inhabiting reef environments in northwestern Atlantic (Williams, 1984; Lindberg \& Stanton, 1988), as well as reported here in this study.

\section{Remark}

The present record confirms the presence of $P$. mutica along the Brazilian Coast; extending its range approximately $4000 \mathrm{~km}$ south $\left(8^{\circ} 30^{\prime} \mathrm{S}-35^{\circ} 00^{\prime} \mathrm{W}\right)$ from its most southerly recorded distribution (Cubagua Island Venezuela) following the coastal contours between both reference points. This confirmation increases to 2 species within the genus Pelia in Brazil. Occurrences have previously been reported off the coast of Brazil in Bahia State (Gouvêa \& Leite, 1980; Gouvêa, 1986), however, according to Coelho et al. (2008) and Almeida \& Coelho (2008) several decapods reported in those first mentioned articles were incorrectly identified and there are no species deposited in marine collection to support the species occurrence. Because of this, the presence of Pelia mutica in Brazil has been considered doubtful before this study.

\section{Discussion}

The human impact on all life on earth, in both terrestrial and marine ecosystems, has been so intense that several scientists have now recognized this period of time as a new geological epoch, the Anthropocene (Zalasiewicz et al., 2010; Steffen et al., 2011; Smith \& Zeder, 2013). In marine ecosystems this era is typified by a defaunation and mass extinction of species driven by human initiated impact factors such as; overfishing with resulting trophic cascade effects, by the introduction of pollutants and alien invasive species (Pinnegar et al., 2000; Shears \& Babcock, 2003; Smith et al., 2011; Stigall, 2012; Säterberg et al. 2013; McCauley et al., 2015). This last factor, the biointroduction of invasive species has been identified as the main reason leading to the great mass extinction during the late Devonian in the Phanerozoic (Stigall,
2012). The implications of which were the breaking of the allopatric barriers and vicariance effects thereby excluding non-generalist species. Large and easy identifiable bioinvasive species like the lion fish Pterois volitans (Linnaeus, 1758) in the Caribbean Sea have received a great deal of attention from the scientific community due its easily identifiable deleterious effects on native reef fish communities (Albins \& Hixon, 2008). However small and supposedly irrelevant alien species within a new ecosystem often start as a silent or unnoticed bioinvader with the potential to quickly spread and impact the associated ecosystem. This pattern of events has been witnessed previously during the supposed insignificant invasion of several species for example; the golden mussel Limnoperna fortunei (Dunker, 1857) in the lakes of south America (Boltovskoy \& Correa, 2015), the zebra mussel Dreissena polymorpha (Pallas, 1771) in Europe (Nalepa \& Schloesser, 1992), the sun coral Tubastraea coccinea (Lesson 1830) in Americas rocky reefs (Sammarco et al., 2010; Da Silva et al., 2014) and the shrimp Litopenaeus vannamei, (Boone, 1931) globally (Liao et al. 2011). The influence of an alien species can reach beyond that of mere competition within a delicately balanced indigenous marine community. In North America in estuaries along the Pacific coast established non-indigenous setting competitor species depressed the survival of the native Olympia oyster Ostrea lurida Carpenter, 1864 by $50 \%$ and retarded its growth by $20 \%$ (Trimble et al., 2009).

In the case of Pelia mutica, it may have been introduced by ballast water or possibly as a result of its popularity with aquarists. As it is was a common ornamental species commercially traded within the aquaria industry (Calado et al., 2003). Another explanation to its presence is that of natural dispersion through the counter-flowing North-Brazilian current, which crosses the biogeographic barrier of the Amazon-Orinoco plume. However large dispersions such as this seems improbable for a small cryptobenthic crab, inhabiting a shallow water niche (Williams, 1984). Floeter et al. (2008) revealed that species with similar characteristics tend to be highly sensitive to sediment discharge and Amazonian freshwater. However several species of reef fish have recently been reported as crossing this biogeographic barrier (Rocha et al., 2007; Rocha et al., 2008; Floeter et al., 2008; Luiz et al., 2013) and it has been shown that other species have migrated south from the Caribbean to Brazil millions of years ago as a result of a weakened current speed in the Amazon-Orinoco barrier (Rocha et al., 2007; Floeter et al., 2008).

It is also quite probable that this insignificant species was simply overlooked and has occurred in Brazil for a period of time, being misidentified as Pelia rotunda, as this is the only species of the genus described in Brazil 
(Melo, 1996). The lack of nocturnal dive surveys when P. mutica is most active (Williams, 1984) may also be a reason for its non-identification. Gouvêa \& Leite (1980) and Gouvêa (1986) identification of Pelia mutica in Bahia state which was considered unconfirmed by Coelho et al. (2008) and Almeida \& Coelho (2008) as there was a lack of preserved and catalogued voucher samples in a recognised marine collection, following the traditional taxonomic methods. This episode of events highlights another current dilemma within all marine biological science, the shortage of skilled taxonomists (Boero, 2010; Pearson et al. 2011). The lack of new and correct systematic identification and the maintenance of relevant species check lists and conserved specimens deposited in marine collections have contributed to the concealment of some inexpressive bio-invasive species. These problems have been exacerbated by the lack of investment in the field of taxonomy with funding focusing on other fields within biological science which are considered more current.

Disregarding the factors as to how P. mutica appeared in Brazilian waters, its presence highlights negligence within the scientific community particularly in relation to the silent bio-invasion of species. Indeed several bioinvasive species have been recorded recently in Brazil such as the Mediterranean golden shrimp Stenopus spinosus Risso, 1827 in (Giraldes \& Freire, 2015), the Indo pacific swimming crab Charybdis hellerii (A. Milne Edwards, 1867) in Tavares \& Mendonça Jr, (1996), the sun coral Tubastraea coccinea (Lesson 1830) and Tubastraea micranthus (Ehrenberg 1834) in Sammarco et al. (2010) and Da Silva et al. (2014). Unfortunately this is a global problem reported in several marine ecoregions of the world (Bax et al., 2003; Molnar et al., 2008). If the previous extinctions of the Devonian are no to be repeated it will be necessary to direct a concerted effort into traditional taxonomic studies and the constant close monitoring of biodiversity species lists.

\section{Acknowledgements}

We would like to thank Dr. Petrônio Alves Coelho for his advice about the importance to analyse all the description, even the ancient ones before conclude a decapod identification. He inspires the revision of the deposited material that results in this discussion.

\section{Authors' contributions}

BWG is the main responsible for the idea and results of this manuscript. DS participate in the discussion and concept of the idea. MC carried out the English revision, the editorial adjustments and some ideas to increase the quality of the manuscript. All authors read and approved the final manuscript.

\section{Competing interests}

The authors declare that they have no competing interest.

\section{Declaration}

- The manuscript was self-funded by authors

- All authors agree to share data but there are no special extra data that makes necessary share a link or citations. Not Applicable.

- None relevant abbreviation was used in the manuscript. Not Applicable.
Received: 2 June 2016 Accepted: 3 June 2016

Published online: 13 July 2016

\section{References}

Abele LG, Kim W. An Illustrated Guide to the Marine Decapod Crustaceans of Florida, Tecnical Series. Florida: Department of Environmental Regulations; 1986. 8(1).

Albins MA, Hixon MA. Invasive Indo-Pacific lionfish Pterois volitans reduce recruitment of Atlantic coral-reef fishes. Mar Ecol Prog Ser. 2008;367:233-8. http://doi.org/10.3354/meps07620.

Almeida AO, Coelho PA. Estuarine and marine brachyuran crabs (Crustacea : Decapoda) from Bahia, Brazil: checklist and zoogeographical considerations. Lat Am J Aquat Res. 2008;36(2):183-222. http://doi.org/10.3856/vol36-issue2fulltext-4.

Bax N, Williamson A, Aguero M, Gonzalez E, Geeves W. Marine invasive alien species: a threat to global biodiversity. Mar Policy. 2003;27(4):313-23. http://doi.org/10.1016/50308-597X(03)00041-1.

Bertini G, Fransozo A, Melo G. Biodiversity of brachyuran crabs (Crustacea: Decapoda) from non-consolidated sublittoral bottom on the northern coast of São Paulo State, Brazil. Biodivers Conserv. 2004;13:2185-207.

Boero F. The Study of Species in the Era of Biodiversity: A Tale of Stupidity. Diversity. 2010;2(1):115-26. http://doi.org/10.3390/d2010115.

Boltovskoy D, Correa N. Ecosystem impacts of the invasive bivalve Limnoperna fortunei (golden mussel) in South America. Hydrobiologia. 2015;746(1):81-95. http://doi.org/10.1007/s10750-014-1882-9.

Boone L. Scientific results of the first oceanographic expedition of the "Pawnee" 1925. Crustacea from tropical east American seas. Bull Bingham Oceanogr Collect. 1927;1:1-147.

Braga AA, Fransozo A, Bertini G, Fumis PB. Composição e abundância dos caranguejos (Decapoda, Brachyura) nas regiões de Ubatuba e Caraguatatuba, litoral norte paulista, Brasil. Biota Neotropica. 2005;5(2):1-34 http://doi.org/10.1590/S1676-06032005000300004.

Calado R, Lin J, Rhyne AL, Araujo R, Narciso L. Marine ornamental decapods popular, pricey and poorly studied. J Crustac Biol. 2003;23(4):963-73.

Coelho PA, Almeida AO, Bezerra LEA. Checklist of the marine and estuarine Brachyura (Crustacea: Decapoda) of northern and northeastern Brazil. Zootaxa. 2008:58:1-58.

Da Silva AG, Paula AF, Fleury BG, Creed JC. Eleven years of range expansion of two invasive corals (Tubastraea coccinea and Tubastraea tagusensis) through the southwest Atlantic (Brazil). Estuar Coast Shelf Sci. 2014;141:9-16. http://doi.org/10.1016/j.ecss.2014.01.013.

Floeter SR, Rocha LA, Robertson DR, Joyeux JC, Smith-Vaniz WF, Wirtz P, Bernardi G. Atlantic reef fish biogeography and evolution. J Biogeogr. 2008;35(1):22-47. http://doi.org/10.1111/j.1365-2699.2007.01790.x.

Fransozo A, Negreiros-Fransozo ML, Mantelatto FLM, Pinheiro MAA, Santos S. Composição e Distribuição dos Brachyura (Crustacea, Decapoda) do Sublitoral não consolidado na Enseada da Fortaleza, Ubatuba (SP). Rev Bras Biol. 1992;52(4):667-75.

Giraldes BW. Decápodes infralitorâneos dos recifes costeiros de Pernambuco, nordeste do Brasil - uma abordagem com Censo Visual Subaquático noturno. PhD Thesis presented in the Universidade Federal de Pernambuco, Brazil; 2012

Giraldes BW, Freire AS. Extending the southern range of four shrimps (Crustacea: Decapoda: Stenopodidae, Hippolytidae and Alpheidae) in southwestern Atlantic (27o S) and confirming the presence of Mediterranean Stenopus spinosus Risso, 1827 in Brazil. Zootaxa. 2015;3:419-31.

Giraldes BW, Coelho Filho PA, Coelho PA. Composition and spatial distribution of subtidal Decapoda on the "Reef Coast", northeastern Brazil, evaluated through a low-impact visual census technique. Nauplius. 2012;20(02):187-201.

Gouvêa EP. A carcinofauna do litoral rochoso de Salvador, BA, e alguns aspectos ecológicos. Ciência E Cultura. 1986;38:346-55.

Gouvêa EP, Leite YM. A carcinofauna do fital da Halimeda opuntia (Linnaeus) Lamoroux e a variação sazonal de sua densidade. Ciência E Cultura. 1980;32: 596-600.

Hernández-Avila I, Gómez A, Lira C, Galindo L. Benthic decapod crustaceans (Crustacea: Decapoda) of Cubagua Island, Venezuela. Zootaxa. 2007;1557:33-45.

Lemaitre R. Shallow-Water Crabs (Decapoda, Brachyura) Collected in the Southern Caribbean Near Cartagena, Colombia. Bull Mar Sci. 1981;31(2):234-66. http://doi.org/10.1016/0198-0254(81)91630-7.

Liao I, Chien Y. The Pacific White Shrimp, Litopenaeus vannamei, in Asia: The World's Most Widely Cultured Alien Crustacean. In: In the Wrong Place-Alien 
Marine Crustaceans: Distribution, Biology and Impacts. Springer Netherlands; 2011. p. 489-519

Lindberg WJ, Stanton G. Bryozoan-associated decapod crustaceans: community patterns and a case of cleaning symbiosis between a shrimp and crab. Bull Mar Sci. 1988:42(3):411-23.

Luiz OJ, Floeter SR, Rocha LA, Ferreira CEL. Perspectives for the lionfish invasion in the South Atlantic: Are Brazilian reefs protected by the currents? Mar Ecol Prog Ser. 2013;485:1-7. http://doi.org/10.3354/meps10383.

McCauley DJ, Pinsky ML, Palumbi SR, Estes JA, Joyce FH, Warner RR. Marine defaunation: Animal loss in the global ocean. Science. 2015. http://doi.org/10.1126/science.1255641

Melo GAS. Manual de identificação dos Brachyura (caranguejos e siris) do litoral Brasileiro. Plêiade, Editora; Fundação de Amparo à Pesquisa do Estado de São Paulo; 1996

Milne-Edwards A. Études sur les Xiphosures et les Crustacés de la région mexicaine, vol. 2. Paris: Imprimerie nationale; 1875.

Molnar JL, Gamboa RL, Revenga C, Spalding MD. Assessing the global threat of invasive species to marine biodiversity. Front Ecol Environ. 2008;6(9):485-92. http://doi.org/10.1890/070064.

Nalepa TF, Schloesser DW. Zebra mussels biology, impacts and control. Lewis, Boca Raton, Florida, USA: CRC Press; 1992.

Ng PKL, Guinot D, Davie PJF. Systema brachyurorum: part I. An annotated checklist of extant brachyuran crabs of the world. Raff Bull Zool. 2008;17:1-286.

Pearson DL, Hamilton AL, Erwin TL. Recovery Plan for the Endangered Taxonomy Profession. Bioscience. 2011;61(1):58-63. http://doi.org/10.1525/bio.2011.61.1.11.

Pinnegar JK, Polunin NVC, Francour P, Badalamenti F, Chemello R, Harmelin-Vivien ML, Pipitone C. Trophic cascades in benthic marine ecosystems: lessons for fisheries and protected-area management. Environ Conserv. 2000;27(2):179-200. http://doi.org/10.1017/S0376892900000205.

Rathbun J. The spider crabs of America. Bull US Nation Museum. 1925;129(i-xx): $1-613$.

Rocha LA, Craig MT, Bowen BW. Phylogeography and the conservation of coral reef fishes. Coral Reefs. 2007;26:501-12. http://doi.org/10.1007/s00338-007-0261-7.

Rocha LA, Rocha CR, Robertson DR, Bowen BW. Comparative phylogeography of Atlantic reef fishes indicates both origin and accumulation of diversity in the Caribbean. BMC Evol Biol. 2008;8:157. http://doi.org/10.1186/1471-2148-8-157.

Sammarco PW, Porter SA, Cairns SD. A new coral species introduced into the Atlantic Ocean - Tubastraea micranthus (Ehrenberg 1834) (Cnidaria, Anthozoa, Scleractinia): An invasive threat? Aquat Invasions. 2010;5(2):131-40. http://doi.org/10.3391/ai.2010.5.2.02.

Säterberg T, Sellman S, Ebenman B. High frequency of functional extinctions in ecological networks. Nature. 2013;499:468-70. http://doi.org/10.1038/nature12277.

Shears N, Babcock R. Continuing trophic cascade effects after 25 years of no-take marine reserve protection. Progress Series: Marine Ecology; 2003.

Smith BD, Zeder MA. The onset of the Anthropocene. Anthropocene. 2013;4:8-13. http://doi.org/10.1016/i.ancene.2013.05.001.

Smith ADM, Brown CJ, Bulman CM, Mackinson S, Marzloff M, Shannon L. Impacts of fishing low-trophic level species on marine ecosystems. Science. 2011;333(October):1147-51.

Spalding MD, Fox HE, Allen GR, Davidson N, Ferdaña ZA, Finlayson M, Robertson J. Marine Ecoregions of the World: A Bioregionalization of Coastal and Shelf Areas. Bioscience. 2007;57(7):573. http://doi.org/10.1641/B570707.

Steffen W, Persson A, Deutsch L, Zalasiewicz J, Williams M, Richardson K, Svedin $U$. The Anthropocene: From global change to planetary stewardship. Ambio. 2011;40:739-61.

Stigall AL. Speciation collapse and invasive species dynamics during the Late Devonian "mass Extinction.". GSA Today. 2012;22(1):4-9. http://doi.org/10. 1130/G128A.1.

Tavares M, Mendonça Jr J. Charybdis hellerii (A. Milne Edwards, 1867) (Brachyura: Portunidae), eighth nonindigenous marine decapod recorded from Brazil. Crustacean Research. 1996:25:151-157

Trimble AC, Ruesink JL, Dumbauld BR. Factors Preventing the Recovery of a Historically Overexploited Shellfish Species, Ostrea lurida Carpenter 1864. J Shellfish Res. 2009;28(1):97-106. http://doi.org/10.2983/035.028.0116.

Williams AB. Shrimps, Lobsters, and Crabs of the Atlantic Coast of the Eastern United States, Maine to Florida. Estuaries. 1984;8:77. http://doi.org/10.2307/1352125.

Zalasiewicz JAN, Williams M, Steffen W, Crutzen P. The new world of the anthropocene. Environ Sci Technol. 2010:44(7):2228-31. http://doi.org/10. 1021/es903118j.

\section{Submit your next manuscript to BioMed Central and we will help you at every step:}

- We accept pre-submission inquiries

- Our selector tool helps you to find the most relevant journal

- We provide round the clock customer support

- Convenient online submission

- Thorough peer review

- Inclusion in PubMed and all major indexing services

- Maximum visibility for your research

Submit your manuscript at www.biomedcentral.com/submit 